\title{
An Economic Model of Locus of Control and the Human Capital Investment Decision ${ }^{1}$
}

\author{
Margo Coleman ${ }^{2} \quad$ Thomas DeLeire ${ }^{3}$
}

August 2000

\begin{abstract}
This paper presents an economic model of how teenagers' outlooks-specifically their locus of control-affects human capital investments. Locus of control, or internal-external attitudes, is a psychological measure of a person's belief regarding the causal relationship between their own behavior and outcomes. The effect of eighth graders' locus of control on their subsequent decisions to complete high school and to attend college is empirically examined using the National Education Longitudinal Study. The results indicate that locus of control does indeed strongly influence the decision to graduate from high school. The model has testable implications that distinguish it from a model in which locus of control is a proxy for unobserved ability. The empirical results suggest that locus of control operates through teenagers' expectations of the returns to human capital investments.
\end{abstract}

${ }^{1}$ The authors would like to thank Joe Altonji, Jay Bhattacharya, Alex Cavallo, Greg Duncan, Rachel Dunifon, Jeff Grogger, and Annamaria Lusardi who provided many useful comments and suggestions and to Steven Dixon who provided research assistance.

${ }^{2}$ Research Associate, Child Welfare League of America, 440 First Street, NW, Third Floor, Washington, DC 200012085.

${ }^{3}$ Assistant Professor, Irving B. Harris Graduate School of Public Policy Studies, University of Chicago, Chicago, IL 60637; E-mail: t-deleire@uchicago.edu 


\section{Introduction}

In most economic models of the decision to complete high school or attend college, individuals weigh the benefits of continuing schooling against those of dropping out. Economic models have typically ignored teenagers' outlooks as a factor relating to their educational decisions. For, example, teenagers who believe that the likelihood that they will find a high paying job depends little on their human capital investments but more on luck, fate, or other "external" factors might be more likely to drop out of high school. On the other hand, teenagers who believe that their human capital investments or other "internal" factors will have a strong impact on their future opportunities might be less likely to drop out of school. Thus, the "internal-external" outlook or "locus of control" of teenagers may have an impact on human capital investment.

Education researchers have long recognized the relationship between locus of control and educational attainment. For example, in 1966, the "Coleman Report" found that locus of control was strongly related to academic achievement. In fact the report found that African-Americans "who gave responses indicating a sense of control of their own fate achieved higher on the tests than those whites who gave the opposite responses. This attitude was more highly related to achievement than any other factor in the student's background or school" (Coleman 1971).

This paper introduces the psychological concept of locus of control into the human capital investment model. It does so by allowing an individual's assessment of the relationship between the probabilities of labor market success and human capital investment to depend upon their internalexternal outlook. This model implies that teenagers with an internal locus of control should be more likely to make educational investments. Importantly, this model has testable implications that distinguish it from a model in which locus of control is simply a proxy for unobserved ability. 
The paper proceeds as follows. Section 2 describes the psychological concept of locus of control and its role in decision making. Section 3 describes past and recent research relating psychological measures and other non-cognitive skills to educational and economic outcomes. Section 4 presents an economic model relating locus of control to a teenager's decision to graduate from high school. Section 5 describes the data used for the empirical analysis, the National Education Longitudinal Survey (NELS). Section 6 reports the results of the empirical analysis and Section 7 provides an empirical test between our model of locus of control and one in which locus of control is a measure of ability. Section 8 provides a discussion of the stability of locus of control. Section 9 concludes.

\section{The Role of Locus of Control in Decision-Making}

Locus of control, or "internal-external" attitudes, is a psychological concept. Psychologists have found that individuals have "a generalized attitude, belief, or expectancy regarding the nature of the causal relationship between one's own behavior and its consequences" that can influence a variety of behavioral decisions in everyday situations (Rotter 1966). Individuals hold beliefs regarding whether situational outcomes are due to his or her own efforts or whether the outcomes are the result of luck, chance, fate or the intervention of others. Individuals who hold beliefs that outcomes are due to their own efforts have an "internal locus of control" while individuals who hold beliefs that outcomes are due to chance have an "external locus of control" (Maddux 1991). Thus, the psychological trait, locus of control, is often referred to as "internal-external attitudes" in the social science and psychology literature.

Locus of control is believed to form during childhood and stabilize during adolescence 
(Sherman 1984). Rotter (1966) hypothesized that an individual develops a generalized expectancy of control when reinforcement is perceived as contingent on his or her behavior. Behaviors that result in reinforcement serve to strengthen the perception of control. On the other hand, when reinforcement fails to occur, the generalized expectancy will be diminished or extinguished. Over time, expectancies for a given situation result from the individual's reinforcement history as well as generalization from other experiences that involve reinforcement. Furthermore, control expectancies are predicted to develop most quickly and be most malleable when then individual has relatively few experiences.

Research appears to support the hypothesis that there is a correlation between chronological age and perception of control (Sherman 1984). Specifically, it is believed that as children age, their perceptions of control become more internal. Sherman studied the developmental trends in perceptions of control in children and adolescents aged 8 to 13 through a combination of crosssectional and longitudinal methodology. Cross-sectional results show that there is a statistically significant increase in internality with increased age. Specifically, there is an increase in internality from ages 8 to 10 , with a general flattening in the trend from ages 11 to 13 . A significant deviation in this trend is evident in the groups of thirteen year olds, who tend to become more external. Longitudinal results are consistent with the cross-sectional results and show a general linear trend toward increasing internality with older children more internal than the younger children. There are no significant differences in this trend based on sex of the children.

Kulas's (1988) study examined the short-term stability of locus of control in young adolescents. His results show that over the course of a year, there were small but insignificant changes in locus of control for both boys and girls. However, there are sex differences in short-term 
stability of locus of control. Specifically, there is significant moderate stability in locus of control for males and insignificant stability in locus of control for girls in early adolescence. Furthermore, Kulas found significant sex differences with girls becoming more external and boys becoming more internal over the course of one year. Kulas hypothesizes that there may be greater stability in locus of control for adolescents who are internally oriented than adolescents who are externally oriented. These results are consistent with earlier longitudinal research that showed that females aged 14 to 24 became more external.

Locus of control has been found to be related to a variety of choices people make in their lives including vocational and career decisions (Maddux 1991). Individuals who have an internal locus of control generally are more active in trying to pursue their goals and improve their lives (Rotter 1966). Furthermore, through ingenuity and perseverance, they often figure out ways of exercising some measure of control even in situations containing limited opportunities and many constraints (Bandura 1990). On the other hand, individuals who believe that they have no control over the outcome of situations are likely to effect little change even in situations that provide many opportunities (Bandura 1990).

Research on the antecedents of individual differences in locus of control is sparse (Carton and Nowicki 1994). However, Carton and Nowicki (1994) reviewed the existing body of literature and drew some general conclusions. First, adults and, in particular, parents appear to influence children's development of control contingencies. Carton and Nowicki (1994) found that the research supports the assumption that consistent parental use of reward and punishment as well as parental encouragement of autonomy are associated with a greater likelihood of the development of generalized internal control expectancies. Second, experiencing stressful life events, particularly if 
disruptive and when young, seems to be associated with a greater likelihood of external control contingencies. Finally, there is empirical support for the assumption that children with generalized internal control expectancies as compared to children with generalized external control expectancies have parents who were more nurturing, emotionally supportive, and warm. In summary, Carton and Nowicki (1994) review of the empirical literature seems to support the influence of early experiences, particularly with parents, on the development of control expectancies. Skinner, ZinnerGembeck, and Connell (1998) examine the development of perceived control in children. They find that parental involvement, family environment, teacher warmth, and academic performance help determine the development if perceived control in children.

Carton and Nowicki's (1994) review, however, highlighted a number of shortcomings in the empirical research. First, while the existing research supports the association between early experiences and control expectancies, the process by which individual differences in control expectancies develop is still unclear. Furthermore, it is unclear the degree to which these findings generalize to the minority populations. Thus, there is still a limited understanding of the developmental process of control expectancies.

\section{Review of the Literature on the Effects of Locus of Control and Perceived Efficacy}

The Survey of Educational Opportunity, as reported in Equality of Educational Opportunity or the "Coleman Report," surveyed six hundred thousand children at five grade levels in four thousand schools. The purpose of the survey was to document the inequalities of educational opportunity experienced by ethnic minorities shortly after the passage of the Civil Rights Act of 1964. Among other findings, the survey found that a measure of the locus of control was highly 
related to academic performance and was a more important determinant of achievement than any other factor in a student's background or school (Coleman 1966).

Andrisani (1977, 1981) used the National Longitudinal Survey (NLS) to study how “initiative”-a four item Rotter (1966) scale measure for locus of control-is related to subsequent labor market outcomes. He found that locus of control was strongly related to average hourly earnings, total earnings, occupational attainment, and the growth of these variables. However, because he found little difference in internal-external attitudes between blacks and whites in his sample, Andrisani concluded that locus of control could not explain substantial amounts of the differences between blacks and whites in labor market outcomes.

Duncan and Morgan (1981) replicated the Andrisani (1977) study using the Panel Study of Income Dynamics (PSID) and using a measure of self-efficacy rather than locus of control. The authors question the causal interpretation of Andrisani's results and suggest that achievement might increase an individual's perceived efficacy. Surprisingly and despite this concern over simultaneity, Duncan and Morgan find much smaller effects using the PSID than Andrisani found with the NLS and concluded that there is little evidence that self-esteem affects labor market outcomes. ${ }^{4}$

In a recent study, Duncan and Dunifon (1998) again use the PSID and find that a measure of self-efficacy for men aged 20-29 does predict labor market outcomes fifteen to twenty years later. Moreover, the self-efficacy of respondents aged 30-39 predicts the number of completed years of schooling of these respondents' children fifteen to twenty years later. The authors conclude "motivation" helps determine economic mobility and can strongly influence both an individual's

${ }^{4}$ Hill et. al. (1985), using additional waves of the PSID, also found small effects of self-efficacy on economic outcomes. 
future wages and the future educational achievement of their children. Moreover, the fact that the of labor market and educational outcomes are measured fifteen to twenty years later should mitigate the concern that self-efficacy and these outcomes are simultaneously determined.

Goldsmith, Veum, and Darity (1997) use measures of self-esteem and locus of control from the National Longitudinal Survey of Youth (NLSY) to test whether "psychological capital" directly effects wages. The authors allow for self-esteem and wages to be determined simultaneously, but obtain identification only though strong exclusion restrictions: the authors assume that locus of control does not directly affect wages but does affect self-esteem. The study concludes that psychological capital directly increases wages through self-esteem and indirectly increases wages through locus of control.

Another recent study, Murnane et al (1997) also uses the NLSY to measure the impact of self-esteem on labor market outcomes. The authors seek to determine whether non-cognitive skills such as interpersonal skills are valued by the labor market in the same way cognitive skills are valued. While the NLSY does have a measure of cognitive skills as measured by the Armed Forces Qualifying Test (AFQT), this survey has no direct measures of non-cognitive skills. The authors instead rely on self-esteem as a measure of these non-cognitive, inter-personal skills. They find that self-esteem both directly increases wages and indirectly increases wages though increased educational attainment. A concern with this type of study is that self-esteem may be more of an outcome than a causal factor in determining labor market and educational achievement.

Other recent work has examined the effects of non-cognitive skills on wages (Heckman, Rubinstein, and Hsee 1998), human capital formation (Heckman 1999), employment (Cavallo 1999), and welfare use (Kunz and Kalil 1999). 
With the exception of Coleman (1966) and Levine and Painter (1998), all of the above studies have focused on labor market outcomes. In this study we focus on the relation between locus of control and the educational outcomes of teenagers using a recent longitudinal survey of the educational attainment of youth, the National Education Longitudinal Survey (NELS).

\section{A Model of Locus of Control and the Human Capital Investment Decision}

In this section, we present a model which incorporates the psychological concept of locus of control into a model of human capital investments including high school completion and college attendance. We model locus of control as influencing a teenager's belief of the return to education. Specifically, teenagers with external locus of control believe that their behavior (e.g., graduating from high school) will have little effect on the probability of getting a "good" job. Teenagers with an internal locus of control believe that their behavior, such as graduating from high school, has a large impact on the probability of getting a "good" job.

In section 4.1, we present the human capital investment model without locus of control. In section 4.2, we add locus of control to the human capital investment model. In section 4.3, we discuss the testable implications of the model with locus of control which distinguish it from a competing model in which locus of control is a proxy for unobserved ability.

\subsection{A Human Capital Investment Model without Locus of Control}

In the human capital investment model, individuals weigh the benefits of continued schooling against the benefits of dropping out when deciding whether to complete additional schooling. Specifically, the decision to graduate is based on the teenagers' estimates of the present discounted value of the monetary and other benefits they expect to receive from each alternative. In this section, 
we present a version of this model.

Let individuals calculate the present value of future wages following Becker(1993). Suppose there are 2 possible income paths, $\bar{y}_{1}$ and $\bar{y}_{2}$, over $T+1$ periods of time where

$$
\begin{aligned}
& \bar{y}_{1}=\left(y_{1}(0), y_{1}(1), y_{1}(2), \ldots y_{1}(T)\right) \\
& \bar{y}_{2}=\left(y_{2}(0), y_{2}(1), y_{2}(2), \ldots y_{2}(T)\right)
\end{aligned}
$$

Suppose that the probability of an individual's receiving income path 1 depends upon her stock of human capital which is assumed to be solely determined by her level of education. Individuals with more schooling will be more productive to firms and are thus more likely to receive the higher wage offers associated with income path 1. Let the probability of receiving income path 1 for high school graduates be $p^{h}$ and the probability of receiving income path 1 for high school dropouts be $p^{d}$. The net present value of expected future wages will differ for high school graduates and high school dropouts. First, individuals who stay in high school cannot work. Thus, if it takes $\mathrm{S}$ periods to complete school, the individual will receive no earnings for the first $\mathrm{S}$ periods. Second, the expected value of wages at time $t$ will differ for high school graduates and high school dropouts as the respective probabilities of receiving income paths 1 and 2 differ. Let the expected value of wages at time $t$ for high school graduates be $E\left[y^{h}(t)\right]$ and that for high school dropouts be $E\left[y^{d}(t)\right]$ and define

$$
\begin{aligned}
& E\left[y^{h}(t)\right]=p^{h} y_{1}(t)+\left(1-p^{h}\right) y_{2}(t) \\
& E\left[y^{d}(t)\right]=p^{d} y_{1}(t)+\left(1-p^{d}\right) y_{2}(t)
\end{aligned}
$$


The net present values of future wages for high school graduates, $V_{0}^{h}$, and high school dropouts, $V_{0}^{d}$

will be

$$
\begin{aligned}
& V_{0}^{h}=\sum_{t=S}^{T} \delta(t) E\left[y^{h}(t)\right] \\
& V_{0}^{d}=\sum_{t=0}^{T} \delta(t) E\left[y^{d}(t)\right]
\end{aligned}
$$

An individual will choose to graduate from high school if $V_{0}^{h}>V_{0}^{d}$ and otherwise will choose to drop-out. Let the index variable $I=1$ if the individual chooses to graduate from high school and let $I=0$ if the individual chooses to drop out. The probability of observing an individual graduating from high school is the probability that the net present value of expected earnings for high school graduation exceeds the net present value of expected earnings for dropping out. That is,

$$
\operatorname{Pr}(I=1)=\operatorname{Pr}\left(V_{0}^{h}>V_{0}^{d}\right)
$$

Let each income path be determined by the following earnings equations

$$
y_{i}(t)=\beta_{i} X(t)+\varepsilon_{i}(t) \quad i=1,2
$$

where the vector $\mathrm{X}$ contains individual and family characteristics. Substituting equations (5) into equations (3) and (4), we get

$$
\operatorname{Pr}(I=1)=\operatorname{Pr}\left(\sum_{t=S}^{T} \delta(t)\left\{p^{h} \beta_{1} X(t)+\left(1-p^{h}\right) \beta_{2} X(t)\right\}>\sum_{t=0}^{T} \delta(t)\left\{p^{d} \beta_{1} X(t)+\left(1-p^{d}\right) \beta_{2} X(t)\right\}\right)
$$


We can estimate the effect of individual and family characteristics on the probability of an individual's graduating from high school with the following reduced-form probit model

$$
\operatorname{Pr}(I=1)=\Phi[\gamma Z(t)]
$$

where $\mathrm{Z}$ contains variables that influence earnings, determine the discount rate, $\delta(t)$, and determine the probabilities of receiving income path 1.

\subsection{Adding Locus of Control to the Human Capital Investment Model}

In this section, we incorporate locus of control-the expectation that individuals have concerning the effectiveness of behaviors in achieving certain outcomes or goals-into the human capital investment model. Unlike much of the previous literature, we introduce locus of control into the model of the decision to graduate from high school without having to resort to assuming that it directly increases productivity as if it were a measure of ability.

Individuals range from external to internal in terms of their locus of control. Let $\theta$ measure a person's locus of control where $\theta$ is continuously distributed on the range $(-\infty, \infty)$; let positive values represent internal locus of control and negative values represent external locus of control. A person's value of $\theta$ will determine their perception of the relative values of $p^{h}$ and $p^{d}$-the probabilities that an individual receives income path 1 if that individual graduates from high school or drops out respectively. Assume that an individual with a value of $\theta$ equal to positive infinity will believe that $p^{h}$ is equal to 1 or, in other words, that by graduating from high school they will receive income path 1 with certainty. Likewise, an individual with a value of $\theta$ equal to infinity will believe that $p^{d}$ - the probability of receiving income path 1 if they drop out - is zero. An individual with 
a value of $\theta$ equal to negative infinity will believe that both $p^{h}$ and $p^{d}$ are equal to $\bar{p}$. Thus, an individual's perceived probabilities of receiving income path 1 is a function of that individual's locus of control..$^{5}$ In particular, let

$$
\begin{aligned}
& p^{h}(\theta)=\Phi[\theta]+(1-\Phi[\theta]) \bar{p} \\
& p^{d}(\theta)=(1-\Phi[\theta]) \bar{p}
\end{aligned}
$$

where $\Phi$ is the standard normal probability distribution function.

Teenagers with more internal locus of control tend to believe that their actions, such as graduating from high school, will influence the likelihood that they receive a high earnings stream while teenagers with more external locus of control tend to believe that graduating from high school has little effect on the likelihood of receiving higher earnings. ${ }^{6}$

Thus, the probability that we observe a teenager graduating from high school is also a function of their locus of control. Substituting equations (8) into equation (6) we get

$$
\begin{aligned}
& \operatorname{Pr}(I=1)= \\
& \operatorname{Pr}\left(\sum_{t=S}^{T} \delta(t)\left\{p^{h}(\theta) \beta_{1} X(t)+\left(1-p^{h}(\theta)\right) \beta_{2} X(t)\right\}>\sum_{t=0}^{T} \delta(t)\left\{p^{d}(\theta) \beta_{1} X(t)+\left(1-p^{d}(\theta)\right) \beta_{2} X(t)\right\}\right)
\end{aligned}
$$

${ }^{5}$ One can justify such a model by appealing to the fact that empirical econometricians have had very difficult time separating the effects of education from those of selection when estimating the returns to education. While teenagers may have a good idea of the distribution of wages in the economy, they might have a more difficult time determining the conditional distribution, especially in light of selection. Thus, as the teenagers are not completely informed on the conditional distribution, psychological traits such as locus of control can have an influence. (See Manski (1993) and Hanushek (1993) for a discussion of these issues.)

${ }^{6}$ Note that we are explicitly not modeling locus of control as a direct determinant of wages (and thus of the value of graduating from high school) as the literature on motivation has done. Modeling locus of control as a direct determinant of wages seems, to us, to be an ad hoc assumption, and we preferred to develop a model in which locus of control influences educational investments and thus wages through its influence on perceived probabilities of outcomes. This approach seems to be more consistent with the concept of locus of control as developed in the psychology literature. We develop a test between our model and a model in which locus of control is a direct determinant of wages in Section 4.3. 
and the reduced-form probit is now

$$
\operatorname{Pr}(I=1)=\Phi[\gamma Z+\alpha \theta]
$$

where $Z$, as before, contains variables that influence earnings as well as variables which determine the discount rate, $\delta(t)$, and $\theta$ is a measure of locus of control.

From data on a random sample of teenagers that includes the variables in $Z, \theta$, and $I$, one can estimate reduced form probit models (equation (10)) to determine the effect of locus of control on the likelihood that teenagers graduate from high school.

\subsection{Implications of the Economic Model of Locus of Control and Comparisons with the a Competing Model of Locus of Control as Unobserved Ability}

The model described by equation (9) and the probit equation (10) implies that increases in locus of control (becoming more internal) should be observed to increase the likelihood that a teenager graduates from high school:

$$
\frac{\partial \operatorname{Pr}(I=1)}{\partial \theta}>0
$$

Since the probit equation relating locus of control with high school graduation (equation (10)) is a reduced form relationship, it is consistent with other structural models of how locus of control might affect human capital investments besides the one described in Section 4.2. For example, our measure of locus of control might simply be picking up unobserved determinants of ability and thus might increase the probability of graduating from high school. That is, the channel by which locus of control affects human capital investment could be quite different than the one we model yet we would still find a positive relationship in our empirical analysis. Therefore, we wish to explore 
implications of our economic model that will distinguish it from a model where locus of control is an unobserved ability characteristic.

In our model, the perceived probability of getting the high wage path conditional upon graduating from high school is greater for teenagers with internal locus of control than for teenagers with external locus of control. Likewise, the perceived probability of getting a high wage path conditional upon dropping out of high school is lower for teenagers with internal locus of control than for teenagers with external locus of control. Teenagers with internal locus of control, recall, believe that their actions will greatly influence what happens to them while teenagers with external locus of control believe outcomes are less related to their actions are perhaps are due to good fortune. This result follows directly from equation (11). Note that:

$$
\begin{aligned}
& \frac{\partial p^{h}(\theta)}{\partial \theta}=\varphi[\theta](1-\bar{p})>0 \\
& \frac{\partial p^{d}(\theta)}{\partial \theta}=-\varphi[\theta] \bar{p}<0
\end{aligned}
$$

Therefore, according to equation (2), teenagers with internal locus of control who graduate from high school should have greater expectations for the future than teenagers with external locus of control who graduate from high school. However, teenagers with internal locus of control who drop out should have lower expectations than teenagers with external locus of control who drop out.

The implications of a model in which locus of control is an unmeasured component of ability differ from the implications of our economic model of locus of control. If teenagers with internal locus of control are simply higher ability teenagers, then they should be more likely to receive the high wage path either as high school graduates or as dropouts than external locus of control 
teenagers. In other words, if our measure of locus of control, $\theta$, is picking up a component of unmeasured ability, $\psi$, then:

$$
\begin{aligned}
& \frac{\partial p^{h}(\psi)}{\partial \psi}>0 \\
& \frac{\partial p^{d}(\psi)}{\partial \psi}>0
\end{aligned} .
$$

Therefore, our economic model of locus of control has testable implications which can distinguish it from a model in which locus of control is a measure of unobserved ability.

Since locus of control is highly correlated with ability, we will use the rich set of measures of cognitive ability available in the NELS as controls in our probit analyses.

\section{Data}

The data for this study consist of the baseline and third follow-up surveys of the National Education Longitudinal Study of 1988 (NELS). The baseline survey was conducted in 1988 and collected background, cognitive, and psychological data from students as well as data from the students' teachers and school. Three follow-up surveys were conducted at two year intervals following the initial baseline survey. Thus, the third follow-up survey occurred in 1994-roughly two years after most students would have graduated from high school. Importantly, as part of the third follow-up survey, information was collected on students' graduation status and college attendance.

The NELS data were taken from a nationally representative sample of 1,000 schools and 25,000 eighth graders were randomly selected from these schools. For the purposes of this study, we use only the roughly 15,000 students on whom complete information was available. 
The NELS contains psychological scales measuring locus-of-control and self-esteem as part of the base-year student questionnaire. Items for the locus-of-control scales were derived from Rotter's internal-external control scale (1966) and are reported in Appendix Table A4. The items were measured on a four point Likert scale from "strongly disagree" to "strongly agree." Each item was individually standardized to a mean of zero and a standard deviation of 1. Each composite scale is the average of the standardized scores of the questionnaire items of which it is composed. Math scores and reading scores are from tests administered in the base year survey, when students were in the eighth grade.

During the third follow-up survey, information was collected on the graduation status of the student. Recall that the third follow-up survey was given six years following the 1988 base-year survey which was given to a random sample of 8th graders. Thus, the third follow-up survey was given about two years after most teenagers would have graduated from high school. Students who did not graduate but received a General Equivalency Diploma (GED) are included with the high school dropouts. ${ }^{7}$

Table 1 reports summary statistics for our entire sample of teenagers and separately for those teenagers who graduated from high school by the time of the third follow-up survey and those who did not. 81 percent of the sample graduated from high school and 59 percent attended college. 11 percent of the sample is black and an additional 9 percent of the sample is Hispanic. 23 percent live in urban neighborhoods and 27 percent live in rural neighborhoods. High school dropouts come from poorer families, are more likely to be black, Hispanic, and to live in urban neighborhoods and in the Midwest than are high school graduates. Moreover, high school dropouts had lower scores in both

\footnotetext{
${ }^{7}$ Cameron and Heckman (1993) suggest that including GED recipients with high school dropouts is appropriate.
} 
math and reading and had more external locus of control in the eighth grade.

\section{Probit Analysis of the Effect of Locus of Control of Education}

We estimate equation (10) using probit analyses for two different dependent variables-high school graduation and college attendance. The data were weighted so as to be representative of a national population. Table 2 reports the key results of the probit models in the form of estimated changes in the probability of graduating from high school or attending college holding all other variables at their mean values. The complete set of results are reported in Appendix Table A1.

Column (1) of Table 2 reports the results of a sparse specification which includes controls for race, ethnicity, gender, region, and the teenager's eighth grade locus of control. Locus of control in the eighth grade is a strong (and statistically significant) predictor of whether the teenager will graduate from high school. A one standard deviation increase in locus of control is estimated to lead to a 6.8 percentage point increase in the likelihood of graduating from high school $(0.068=0.738$ $\mathrm{x}$ 0.092). In this specification, black teenagers are estimated to be 9 percentage points less likely than white teenagers to graduate from high school and Hispanic teenagers are estimated to be 7 percentage points less likely to graduate from high school. Females are 2.6 percentage points more likely than males to graduate from high school.

Column (2) reports the results of a specification which also includes results from reading, math, science, and history tests given in the eighth grade, grades, and controls for father's and mother's education. Math ability in the $8^{\text {th }}$ grade is highly correlated with the teenager's eventual high school graduation status 6 years later. Reading, science, and history scores, on the other hand, neither have a sizeable nor a statistically significant effect on the likelihood that a teenager will 
graduate from high school. (The marginal effects of science and history scores are only reported in the Appendix.) Including the additional controls reduces the estimated difference in graduation rates between black and Hispanic teenagers and white teenagers to a level not significantly different from zero. Similarly, the difference between females and males is no longer statistically different from zero. The marginal effect of locus of control, with the inclusion of the additional controls for test scores and parents education, has become smaller but is still statistically significant. A one standard deviation increase in locus of control is estimated to lead to a 1.6 percentage point increase in the probability of graduating from high school $(0.016=0.738 \times 0.022)$. The effect of locus control on high school graduation is large, but not quite as large as the effect of math ability. For comparison, note that a one standard deviation increase in math ability is estimated to increase the probability of graduating from high school by 5 percentage points $(0.050=10.07 \times 0.005)$.

Column (3) reports the results of a specification which also includes a set of parenting variables. The estimated effects change little from the effects reported in Column (2), except in now Hispanic teenagers are estimated to be 1.8 percentage points more likely to graduate from high school than white teenagers and this difference is statistically significant. Column (4) also includes controls for family structure in the $8^{\text {th }}$ grade and for whether the teenager's family experiences any changes in their family structure between the teenager's $8^{\text {th }}$ and $12^{\text {th }}$ grades. Again, very little changes from Column (3). In this most expansive specification, the marginal effect of locus of control is large and statistically significant. A one standard deviation increase in locus of control is estimated to lead to a 1.4 percentage point increase in the probability of graduating from high school.

Columns (5) through (8) report similar specifications for the probability that the teenager has attended any college by the time of the third follow-up survey, six years following the initial $8^{\text {th }}$ grade 
survey. Column (5) reports the results of the sparse specification with only controls for race/ethnicity, gender, region, and locus of control. Black teenagers are estimated to be 13 percentage points less likely to attend college. Hispanic teenagers are estimated to be 11 percentage points less likely to attend college. Female teenagers are estimated to be 7 percentage points more likely to attend college. Eighth grade locus of control has a large and statistically significant impact of the probability of graduating from high school. A one standard deviation increase in locus of control is estimated to increase the probability of attending college by 11.6 percentage points.

Columns (6), (7), and (8) add controls for test scores and parents education, parenting behavior, and family structure respectively. In the most expansive specification, reported in Column (8), black and Hispanic teenagers are 3.5 and 7.3 percentage points more likely than white teenagers to attend college. Females are 6.7 percentage points more likely to attend college than males. A one standard deviation increase in math ability leads to a 9 percentage point increase in the probability of college attendance while a one standard deviation increase in reading ability leads to a 2 percentage point increase in the probability of college attendance. Locus of control remains an important and statistically significant determinant of college attendance. A one standard deviation increase in locus of control is estimated to increase the probability of attending college by 3.2 percentage points.

Table 3 reports the key results of probit models for high school graduation and college attendance which allow for a different effect of locus of control by race and ethnicity. The full set of results are reported in Appendix Table A2. Locus of control has a larger influence on the likelihood that Hispanic teenagers graduate from high school. The effect of locus of control on high school graduation is equal for black and white students. The effect of locus of control on the 
likelihood of college attendance is larger for black teenagers than for white or Hispanic teenagers.

\section{Testing the Implications of the Economic Model of Locus of Control Versus a Model in which Locus of Control is a Measure of Unobserved Ability}

In Section 4.3, we describe some implications of our economic model of locus of control that differ from a model in which locus of control is simply measuring an unobserved component of ability. In our model, teenagers with internal locus of control believe that they will be more likely to achieve a "high wage path" conditional upon graduating from high school than do teenagers with external locus of control. Conversely, teenagers with internal locus of control believe that conditional upon not graduating from high school, they will be less likely to achieve a "high wage path" than do teenagers with external locus of control. If locus of control were a component of ability, then higher ability students should expect to do better conditional upon graduating from high school and conditional upon not graduating from high school.

Fortunately, in the NELS we have two measures of teenager's expectations for the future that we can use to directly test between the economic model of locus of control and the ability model of locus of control. The two measures are "expected income at age 30" and "expected occupation." We coded the expected occupations into high-skill and low-skill jobs. Our model implies that teenagers with internal locus of control should expect higher incomes and to be in higher skilled occupations conditional upon graduating from high school, than do teenagers with external locus of control. In addition, teenagers with internal locus of control should expect lower incomes and to be less likely to be in a high skilled occupation, conditional upon not graduating from high school, than teenagers with external locus of control. If locus of control is a measure of ability, then teenagers 
with internal locus of control should expect higher incomes and to be more likely to be in a high skilled occupation than external teenagers whether we condition upon high school graduation or not.

To test between these competing hypotheses, we estimate the following regression models:

$$
\begin{aligned}
E I & =\beta X+\gamma_{1} \text { Internal }+\gamma_{2} \text { Neutral } \\
& +\delta_{1} \text { Internal } * \text { HSgrad }+\delta_{2} \text { Neutral } * \text { HSgrad }+\delta_{3} \text { HSgrad }+v \\
E O & =\beta X+\gamma_{1} \text { Internal }+\gamma_{2} \text { Neutral } \\
& +\delta_{1} \text { Internal } * \text { HSgrad }+\delta_{2} \text { Neutral } * H S g r a d+\delta_{3} \text { HSgrad }+v
\end{aligned}
$$

$E I$ is a measure of expected income and $E O$ is a measure of expected likelihood of being in a high skilled occupation. Internal is a dummy variable which is one if the teenager's $8^{\text {th }}$ grade locus of control is in the top quartile of scores. External is a dummy variable equal to one if the teenager's locus of control is in the bottom quartile. Neutral is equal to one if locus of control is between the $25^{\text {th }}$ and $75^{\text {th }}$ percentiles. Hsgrad is a dummy variable equal to one if the teenager has graduated from high school by the time of the third follow-up survey.

In addition to these tests of the model, we also explore whether eighth grade math ability is increasing with internal locus of control among both high school graduates and high school dropouts. If math ability is not increasing with locus of control, our test distinguishing our model from a model of unobserved ability likely will have little power.

$$
\begin{aligned}
\text { Math } & =\beta X+\gamma_{1} \text { Internal }+\gamma_{2} \text { Neutral } \\
& +\delta_{1} \text { Internal } * \text { HSgrad }+\delta_{2} \text { Neutral } * H S g r a d+\delta_{3} H S g r a d+v
\end{aligned} .
$$


Table 4 reports the results from regressions estimating equations (14)-(16). The first three columns of Table 4 report the results for expected income; the middle three columns report the results for expected probability of being in a high skilled occupation; the last three columns report the results for math achievement. These full regression results are reported in Appendix Table A3.

Column (1) of Table 4 reports predicted expected income for three groups, those with internal, neutral, and external locus of control. Controls include race, ethnicity, gender, region, and whether the teenager lives in an urban or rural area. Internal teenagers expect a greater amount of income than either neutral or external teenagers, but the expectations for the three groups are not statistically significantly different from one another.

Column (2) of Table 4 reports predicted expected income for six groups-high school graduates with internal, neutral, and external locus of control and high school dropouts with internal, neutral, and external locus of control without additional controls. Internal high school graduates expect to receive greater levels of income than external high school graduates. However, internal high school dropouts expect to receive lower levels income than external high school dropouts. The same pattern is exhibited in Column (3), which reports a specification that also controls for race, ethnicity, gender, region, and whether the teenager lives in an urban or rural area. Internal high school graduates expect to earn more than external high school graduates. However, internal high school dropouts expect to earn less than external high school dropouts.

Columns (4) through (6) report predicted probabilities of being in a high skill occupation and a similar pattern of results is found. Internal high school graduates are more likely to expect to be in a high skill occupation than are external high school graduates. Internal high school dropouts, on the other hand, are less likely to expect to be in a high skill occupation than are external dropouts. 
Note that this pattern of results for income and occupational expectations are exactly the pattern predicted by our human capital investment model incorporating locus of control. The pattern of results are inconsistent with a model in which locus of control is a proxy for unobserved ability.

To add assurances that the pattern of results reported in the first six columns of Table 4 are inconsistent with a model of ability, the last three columns present results for math achievement. Internal high school graduates reports higher math achievement than do external high school graduates. In addition, internal high school dropouts also report high math achievement than do external high school dropouts. This pattern is, as expected, consistent with a model of achievement.

Because internal dropouts have worse expectations than do external dropouts, and because the pattern of expectations differs from that for math ability, the results Table 4 support our economic model in which locus of control affects teenager's evaluation of the probability of receiving a "high wage path" conditional upon educational investments. The patterns for expected income and occupation are not consistent, however, with a model in which locus of control is a measure of ability.

\section{Discussion and Robustness Checks}

Our results reported in Section 6 show that having an internal locus of control is an important determinant of educational attainment. Because the effect of locus of control on educational attainment is robust to the inclusion of a wide set of ability, parenting, and family structure controls, it is measuring something different form these variables. While locus of control is correlated with cognitive ability it is measuring something distinct. Our model of locus of control implies that internal teenagers who fail to invest in education should expect to have worse outcomes than external 
teenagers who fail to invest in education. This implication is not implied if locus of control is a measure of ability. Higher ability teenagers should uniformly expect to have better outcomes. The empirical evidence supports our model of locus of control and rejects a model that considers locus of control a measure of ability.

A major concern remain. How is a teenager's locus of control formed? The psychological literature suggests that early achievement helps determine a teenager's locus of control. Moreover, a teenager's locus of control is still being formed when he or she is in the $8^{\text {th }}$ grade. Using the NELS, we can determine how stabile a teenager's locus of control is between the $8^{\text {th }}, 10^{\text {th }}$, and $12^{\text {th }}$ grades.

Table 5 reports correlations between locus of control measured in the $8^{\text {th }}, 10^{\text {th }}$, and $12^{\text {th }}$, grades. The correlation of locus of control between ages is positive, but only moderately in size-roughly 0.3 to 0.4 . Cognitive skills, on the other hand, exhibit very high correlations across ages. Tables 6 and 7 respectively report correlations of math and reading tests in the $8^{\text {th }}, 10^{\text {th }}$, and $12^{\text {th }}$ grades. The correlations for math ability are the highest-roughly 0.8 to 0.9 -while the correlations for reading ability are only slightly smaller-roughly 0.7 to 0.8 .

\section{Conclusion}

The economic model presented in Section 4 suggests that locus of control will influence a teenager's decision to graduate from high school. It does so through its effect of a teenager's perception of the link between his or her actions (graduate from high school) and subsequent outcomes (the likelihood of receiving high wages). This model has the attractive features of both being consistent with most human capital models and with psychologists' concept of locus of control. The empirical results show that eighth-grade locus of control does indeed exhibit a strong 
influence on teenagers' graduation decisions. The effect of locus of control on the decision to graduate is large and robust to the inclusion of a wide set of ability, parenting, and family structure variables. Importantly, the patterns of teenager's expectations are consistent with our model of locus of control and are not consistent, however, with a model in which locus of control is a measure of ability.

In conclusion, it appears that modeling psychological factors in economic models can assist in understanding human capital investment decisions. Furthermore, these models can help guide empirical work which in turn may provide useful information for the development of effective public policy programs for high school dropouts. Future research should more fully examine the role of these and other psychological factors in teenagers' decision-making process. 


\section{References}

Andrisani, Paul J. (1977). "Internal-External Attitudes, Personal Initiative, and the Labor Market Experience of White and Black Men.” Journal of Human Resources, 12(3):308-28.

----- (1981). “Internal-External Attitudes, Sense of Efficacy, and Labor Market Experience: A Reply to Duncan and Morgan." Journal of Human Resources, 16(4):658-66.

Bandura, Albert (1990). "Reflections on Nonability Determinants of Competence." In R.J. Sternberg \& J. Kolligan, Jr. (eds.), Competence Considered. New Haven, CT: Yale University Press.

Becker, Gary S. (1993). Human Capital: A Theoretical and Empirical Analysis with Special Reference to Education, 3rd Ed. Chicago, IL: The University of Chicago Press.

Blank, Rebecca M. (1997). It Takes a Nation: A New Agenda for Fighting Poverty. New York: Russell Sage Foundation.

Cameron, Stephen and James Heckman (1993). "The Nonequivalence of High School Equivalents." Journal of Labor Economics 11(1) Part 1: 1-47.

Cavallo, Alex (1999). “The Labor Market Effects of Personality Characteristics.” Manuscript, University of Chicago.

Coleman, James S. (1966). Equality of Educational Opportunity/United States Office of Education. Washington D.C.: U.S. Government Printing Office.

---- (1971). “Equal Schools or Equal Students?” In David M. Gordon (ed.) Problems in Political Economy: An Urban Perspective. Lexington, MA: D.C. Health and Co.

Duncan, Greg and James Morgan (1981). "Sense of Efficacy and Changes in Economic Status--A Comment on Andrisani." Journal of Human Resources, 16(4):649-57.

Duncan, Greg J. and Rachel Dunifon. (1998) "Soft Skills and Long-Run Labor Market Success," In Research in Labor Economics, Vol. 17, S. Polochek, ed. Stamford, CT: JAI Press: 123-149.

Dunifon, Rachel and Greg J. Duncan. (1998.) "Long-Run Effects of Motivation on Labor-Market Success," Social Psychology Quarterly, 61(1): 33-48.

Goldsmith, Arthur H., Jonathan R. Veum, and William Darity (1997). “The Impact of Psychological and Human Capital on Wages." Economic Inquiry, 35(4):815-29. 
Hanushek, Eric A. (1993). "Comment on Adolescent Econometricians: How Do Youth Infer the Returns to Schooling?" In Studies of Supply and Demand in Higher Education, edited by Charles T. Clotfelter and Michael Rothschild, Chicago: University of Chicago Press.

Heckman, James, Yona Rubinstein, and Jing Jing Hsee (1998). “The GED Is a Mixed Signal." Manuscript, University of Chicago.

Heckman, James (1999). “Policies to Foster Human Capital.” Manuscript, University of Chicago.

Hill M, et. al. (1985). Motivation and Economic Mobility. Ann Arbor: Institute for Social Research.

Kunz, James and Ariel Kalil (1999). "Self-esteem, self-efficacy, and welfare use. Social Work Research 23(2): 119-126.

Maddux, James E. (1991). "Self-Efficacy." In C.R. Snyder and Donelson R. Forsyth, (Eds.), Handbook of social and clinical psychology: The health perspective. New York: Pergamon Press.

Manski, Charles F. (1993). "Adolescent Econometricians: How Do Youth Infer the Returns to Schooling? in Studies of Supply and Demand in Higher Education," edited by Charles T. Clotfelter and Michael Rothschild, Chicago: University of Chicago Press.

Murnane, Richard J., John B. Willett, M. Jay Braatz and Yves Duhaldeborde (1997). "Does the Self-Esteem of High-School-Aged Males Predict Labor Market Success a Decade Later?" Evidence from the NLSY." Harvard University Graduate School of Education, unpublished manuscript.

Rotter, Julian B. (1966). "Generalized Expectancies for Internal Versus External Control of Reinforcement." Reprinted in J. B. Rotter, J. E. Chance \& E. J. Phares, Applications of a Social Learning Theory of Personality. New York: Holt, Rinehart and Winston, Inc.

Skinner, Ellen A., Melanie J. Zimmer-Gembeck, and James P. Connell (1998). "Individual Differences and the Development of Perceived Control." Monographs of the Society for Research in Child Development. 63(2-3, Serial No. 254).

Willis, Robert J. and Sherwin Rosen (1979). "Education and Self-Selection.” Journal of Political Economy, 87(5) part 2: S7-S36. 
Table 1: Summary Statistics for the Entire Sample and by High School Graduation Status

\begin{tabular}{|c|c|c|c|}
\hline & (1) & (2) & (3) \\
\hline & Whole Sample & High School Graduates & High School Dropouts \\
\hline High School Graduate & $0.808(0.394)$ & 1 & 0 \\
\hline Attended College & $0.590(0.492)$ & $0.731(0.444)$ & 0 \\
\hline Locus of Control ( $8^{\text {th }}$ Grade $)$ & $0.009(0.738)$ & $0.080(0.701)$ & $-0.328(0.812)$ \\
\hline Math & $50.546(10.070)$ & $51.939(9.987)$ & $43.646(7.240)$ \\
\hline Reading & $50.476(10.043)$ & $51.681(9.967)$ & $44.545(8.134)$ \\
\hline Grade Point Average ( $8^{\text {th }}$ Grade) & $2.897(0.764)$ & $3.030(0.697)$ & $2.254(0.745)$ \\
\hline Any Disability & $0.144(0.351)$ & $0.126(0.332)$ & $0.217(0.412)$ \\
\hline Black & $0.112(0.316)$ & $0.101(0.302)$ & $0.158(0.365)$ \\
\hline Hispanic & $0.090(0.286)$ & $0.084(0.278)$ & $0.115(0.319)$ \\
\hline Female & $0.439(0.496)$ & $0.456(0.498)$ & $0.366(0.482)$ \\
\hline Urban & $0.226(0.418)$ & $0.224(0.417)$ & $0.235(0.424)$ \\
\hline Rural & $0.273(0.446)$ & $0.279(0.448)$ & $0.250(0.433)$ \\
\hline Father HS Grad & $0.242(0.429)$ & $0.245(0.430)$ & $0.230(0.421)$ \\
\hline Father Some Coll & $0.150(0.357)$ & $0.164(0.370)$ & $0.092(0.289)$ \\
\hline Father Coll Grad & $0.215(0.411)$ & $0.251(0.433)$ & $0.066(0.249)$ \\
\hline Mother HS Grad & $0.291(0.454)$ & $0.295(0.456)$ & $0.271(0.445)$ \\
\hline Mother Some Coll & $0.173(0.379)$ & $0.187(0.390)$ & $0.115(0.319)$ \\
\hline Mother Coll Grad & $0.182(0.386)$ & $0.207(0.405)$ & $0.078(0.269)$ \\
\hline Discuss w/ Parents & $0.671(0.470)$ & $0.710(0.454)$ & $0.505(0.500)$ \\
\hline Encyclopedia & $0.756(0.429)$ & $0.793(0.405)$ & $0.601(0.490)$ \\
\hline Newspaper & $0.769(0.422)$ & $0.802(0.399)$ & $0.629(0.483)$ \\
\hline Parents Attend & $0.770(0.421)$ & $0.799(0.401)$ & $0.650(0.477)$ \\
\hline Check Homework & $0.389(0.487)$ & $0.399(0.490)$ & $0.344(0.475)$ \\
\hline Limit TV & $0.400(0.490)$ & $0.417(0.493)$ & $0.326(0.469)$ \\
\hline Place to Study & $0.334(0.472)$ & $0.346(0.476)$ & $0.280(0.449)$ \\
\hline Family Income & $35035(40601)$ & $38925(42828)$ & $18648(23102)$ \\
\hline Family Size & $4.622(1.429)$ & $4.604(1.371)$ & $4.710(1.680)$ \\
\hline 2 Parent Family & $0.557(0.497)$ & $0.610(0.488)$ & $0.330(0.470)$ \\
\hline Step-parent & $0.093(0.291)$ & $0.089(0.285)$ & $0.110(0.313)$ \\
\hline Single Parent & $0.128(0.334)$ & $0.115(0.319)$ & $0.180(0.384)$ \\
\hline Cohabiting & $0.039(0.195)$ & $0.032(0.177)$ & $0.069(0.253)$ \\
\hline 3 Generation & $0.015(0.121)$ & $0.014(0.117)$ & $0.019(0.137)$ \\
\hline Other Family Structure & $0.168(0.374)$ & $0.139(0.346)$ & $0.292(0.455)$ \\
\hline No Family Structure Change & $0.677(0.468)$ & $0.714(0.452)$ & $0.521(0.500)$ \\
\hline Observations & 14915 & 12500 & 2415 \\
\hline
\end{tabular}

Note: Statistics are weighted. Standard errors are reported in parentheses. 
Table 2: Effects of Locus of Control on Educational Attainment: Marginal Effects from a Probit Analysis

\begin{tabular}{|c|c|c|c|c|c|c|c|c|}
\hline \multirow[b]{3}{*}{ Black } & (1) & (2) & (3) & (4) & (5) & (6) & (7) & (8) \\
\hline & \multicolumn{4}{|c|}{ Graduated from High School } & \multicolumn{4}{|c|}{ Attended College } \\
\hline & $\begin{array}{l}-0.091 \\
(0.011)^{* *}\end{array}$ & $\begin{array}{l}-0.013 \\
(0.008)\end{array}$ & $\begin{array}{l}-5.3 \mathrm{e} 6 \\
(0.008)\end{array}$ & $\begin{array}{l}0.014 \\
(0.007)\end{array}$ & \begin{tabular}{|l}
-0.133 \\
$(0.014)^{* *}$
\end{tabular} & $\begin{array}{l}-0.006 \\
(0.015)\end{array}$ & $\begin{array}{l}0.020 \\
(0.014)\end{array}$ & $\begin{array}{l}0.035 \\
(0.015)^{*}\end{array}$ \\
\hline Hispanic & $\begin{array}{l}-0.066 \\
(0.012)^{* * *}\end{array}$ & $\begin{array}{l}0.008 \\
(0.008)\end{array}$ & $\begin{array}{l}0.018 \\
(0.008)^{*}\end{array}$ & $\begin{array}{l}0.016 \\
(0.008)^{*}\end{array}$ & $\begin{array}{l}-0.110 \\
(0.015)^{* *}\end{array}$ & $\begin{array}{l}0.039 \\
(0.015)^{* *}\end{array}$ & $\begin{array}{l}0.065 \\
(0.015)^{* *}\end{array}$ & $\begin{array}{l}0.073 \\
(0.015)^{* *}\end{array}$ \\
\hline Female & $\begin{array}{l}0.026 \\
(0.006)^{* *}\end{array}$ & $\begin{array}{l}0.010 \\
(0.006)\end{array}$ & $\begin{array}{l}0.010 \\
(0.005)\end{array}$ & $\begin{array}{l}0.011 \\
(0.005)^{*}\end{array}$ & $\begin{array}{l}0.070 \\
(0.008) * *\end{array}$ & $\begin{array}{l}0.060 \\
(0.010)^{* *}\end{array}$ & $\begin{array}{l}0.061 \\
(0.010)^{* *}\end{array}$ & $\begin{array}{l}0.067 \\
(0.010)^{* *}\end{array}$ \\
\hline Locus of Control & $\begin{array}{l}0.092 \\
(0.004) * *\end{array}$ & $\begin{array}{l}0.022 \\
(0.004)^{* *}\end{array}$ & $\begin{array}{l}0.019 \\
(0.004)^{* *}\end{array}$ & $\begin{array}{l}0.019 \\
(0.004)^{* *}\end{array}$ & $\mid \begin{array}{l}0.157 \\
(0.006)^{* *}\end{array}$ & $\begin{array}{l}0.051 \\
(0.007)^{* *}\end{array}$ & $\begin{array}{l}0.044 \\
(0.007)^{* *}\end{array}$ & $\begin{array}{l}0.043 \\
(0.007)^{* * *}\end{array}$ \\
\hline GPA $\left(8^{\text {th }}\right.$ grade $)$ & $\begin{array}{l}- \\
-\end{array}$ & $\begin{array}{l}0.099 \\
(0.004)^{* *}\end{array}$ & $\begin{array}{l}0.094 \\
(0.004)^{* *}\end{array}$ & $\begin{array}{l}0.086 \\
(0.004)^{* *}\end{array}$ & $\begin{array}{l}- \\
-\end{array}$ & $\begin{array}{l}0.176 \\
(0.007)^{* *}\end{array}$ & $\begin{array}{l}0.171 \\
(0.007)^{* *}\end{array}$ & $\begin{array}{l}0.162 \\
(0.008)^{* *}\end{array}$ \\
\hline Math & $\begin{array}{l}- \\
-\end{array}$ & $\begin{array}{l}0.005 \\
(.0005)^{* *}\end{array}$ & $\begin{array}{l}0.005 \\
(.0005)^{* *}\end{array}$ & $\begin{array}{l}0.005 \\
(.0005)^{* *}\end{array}$ & - & $\begin{array}{l}0.010 \\
(0.001)^{* *}\end{array}$ & $\begin{array}{l}0.009 \\
(0.001)^{* *}\end{array}$ & $\begin{array}{l}0.009 \\
(0.001)^{* *}\end{array}$ \\
\hline Reading & $\begin{array}{l}- \\
-\end{array}$ & $\begin{array}{l}-0.0004 \\
(0.0005)\end{array}$ & $\begin{array}{l}-0.001 \\
(0.0005)\end{array}$ & $\begin{array}{l}-0.0005 \\
(0.0005)\end{array}$ & $\begin{array}{l}- \\
-\end{array}$ & $\begin{array}{l}0.002 \\
(0.001)^{* * *}\end{array}$ & $\begin{array}{l}0.002 \\
(0.001)^{*}\end{array}$ & $\begin{array}{l}0.002 \\
(0.001)^{* * *}\end{array}$ \\
\hline Parents Info & No & Yes & Yes & Yes & No & Yes & Yes & Yes \\
\hline Parenting Controls & No & No & Yes & Yes & No & No & Yes & Yes \\
\hline Family Structure & No & No & No & Yes & No & No & No & Yes \\
\hline Observations & 13720 & 13009 & 13009 & 12896 & 13720 & 13009 & 13009 & 12896 \\
\hline
\end{tabular}

Standard errors in parentheses. All models include controls for region.

* significant at $5 \%$ level; ** significant at $1 \%$ level 
Table 3: Effects of Locus of Control on Educational Attainment: Marginal Effects from a Probit Analysis (with Race and Gender Interactions)

\begin{tabular}{|c|c|c|c|c|c|c|c|c|}
\hline \multirow[b]{3}{*}{$\begin{array}{l}\text { Locus of Control } \\
* \text { White }\end{array}$} & (1) & (2) & (3) & (4) & (5) & (6) & (7) & (8) \\
\hline & \multicolumn{4}{|c|}{ Graduate from High School } & \multicolumn{4}{|c|}{ Attend College } \\
\hline & $\begin{array}{l}0.085 \\
(0.036)^{* *}\end{array}$ & $\begin{array}{l}0.018 \\
(0.004)^{* *}\end{array}$ & $\begin{array}{l}0.018 \\
(0.004)^{* *}\end{array}$ & $\begin{array}{l}0.018 \\
(0.004) * *\end{array}$ & $\begin{array}{l}0.144 \\
(0.007)^{* *}\end{array}$ & $\begin{array}{l}0.033 \\
(0.008) * *\end{array}$ & $\begin{array}{l}0.027 \\
(0.008)^{* *}\end{array}$ & $\begin{array}{l}0.027 \\
(0.008)^{* * *}\end{array}$ \\
\hline $\begin{array}{l}\text { Locus of Control } \\
\text { * Black }\end{array}$ & $\begin{array}{l}0.103 \\
(0.038)^{* *}\end{array}$ & $\begin{array}{l}0.028 \\
(0.009) * *\end{array}$ & $\begin{array}{l}0.018 \\
(0.009)^{*}\end{array}$ & $\begin{array}{l}0.018 \\
(0.009)^{*}\end{array}$ & $\begin{array}{l}0.164 \\
(0.033) * *\end{array}$ & $\begin{array}{l}0.074 \\
(0.018)^{* *}\end{array}$ & $\begin{array}{l}0.066 \\
(0.018) * *\end{array}$ & $\begin{array}{l}0.061 \\
(0.018) * *\end{array}$ \\
\hline $\begin{array}{l}\text { Locus of Control } \\
* \text { Hispanic }\end{array}$ & $\begin{array}{l}0.122 \\
(0.038)^{* *}\end{array}$ & $\begin{array}{l}0.040 \\
(0.011)^{* *}\end{array}$ & $\begin{array}{l}0.032 \\
(0.010)^{* *}\end{array}$ & $\begin{array}{l}0.032 \\
(0.010)^{* *}\end{array}$ & $\begin{array}{l}0.152 \\
(0.035)^{* *}\end{array}$ & $\begin{array}{l}0.031 \\
(0.019)\end{array}$ & $\begin{array}{l}0.027 \\
(0.019)\end{array}$ & $\begin{array}{l}0.027 \\
(0.019)\end{array}$ \\
\hline $\begin{array}{c}\text { Black - White } \\
\text { Difference }\end{array}$ & $\begin{array}{l}0.018 \\
(0.013)\end{array}$ & $\begin{array}{l}0.009 \\
(0.010)\end{array}$ & $\begin{array}{l}0.007 \\
(0.010)\end{array}$ & $\begin{array}{l}0.000 \\
(0.010)\end{array}$ & $\begin{array}{l}0.020 \\
(0.017)\end{array}$ & $\begin{array}{l}0.041 \\
(0.014)^{* *}\end{array}$ & $\begin{array}{l}0.038 \\
(0.013) * *\end{array}$ & $\begin{array}{l}0.034 \\
(0.013) * *\end{array}$ \\
\hline $\begin{array}{l}\text { Hispanic - White } \\
\text { Difference }\end{array}$ & $\begin{array}{l}0.037 \\
(0.013)^{* *}\end{array}$ & $\begin{array}{l}0.022 \\
(0.010) * *\end{array}$ & $\begin{array}{l}0.021 \\
(0.010)^{* *}\end{array}$ & $\begin{array}{l}0.013 \\
(0.010)\end{array}$ & $\begin{array}{l}0.008 \\
(0.018)\end{array}$ & $\begin{array}{l}-0.003 \\
(0.014)\end{array}$ & $\begin{array}{l}-0.0002 \\
(0.014)\end{array}$ & $\begin{array}{l}0.000 \\
(0.014)\end{array}$ \\
\hline
\end{tabular}

Standard errors in parentheses

* significant at $5 \%$ level; ** significant at $1 \%$ level 
Table 4: Income Expectations and Math Achievement

\begin{tabular}{|c|c|c|c|c|c|c|c|c|c|}
\hline & (1) & (2) & (3) & (4) & $(5)$ & (6) & (7) & $(8)$ & (9) \\
\hline & \multicolumn{3}{|c|}{ Income Expectations } & \multicolumn{3}{|c|}{ Occupation Expectations } & \multicolumn{3}{|c|}{ Math Achievement } \\
\hline \multicolumn{10}{|c|}{ High School Graduates and Dropouts } \\
\hline $\begin{array}{l}\text { Internal Locus } \\
\text { of Control }\end{array}$ & $\begin{array}{l}46988 \\
(1943)\end{array}$ & - & - & $\begin{array}{c}0.442^{\dagger} \\
(0.008)\end{array}$ & - & - & $\begin{array}{c}53.23^{\dagger} \\
(0.240)\end{array}$ & - & - \\
\hline $\begin{array}{l}\text { Average Locus } \\
\text { of Control }\end{array}$ & $\begin{array}{l}46181 \\
(2511)\end{array}$ & - & - & $\begin{array}{c}0.434^{\dagger} \\
(0.011)\end{array}$ & - & - & $\begin{array}{l}51.11^{\dagger} \\
(0.239)\end{array}$ & - & - \\
\hline $\begin{array}{l}\text { External Locus } \\
\text { of Control }\end{array}$ & $\begin{array}{l}45980 \\
(2688)\end{array}$ & - & - & $\begin{array}{c}0.324 \\
(0.011)\end{array}$ & - & - & $\begin{array}{c}47.33 \\
(0.255)\end{array}$ & - & - \\
\hline \multicolumn{10}{|c|}{ High School Graduates } \\
\hline $\begin{array}{l}\text { Internal Locus } \\
\text { of Control }\end{array}$ & - & $\begin{array}{l}49426^{*} \\
(1556)\end{array}$ & $\begin{array}{l}48788 \\
(2116)\end{array}$ & - & $\begin{array}{c}0.442^{\dagger} \\
(0.007)\end{array}$ & $\begin{array}{c}0.478^{\dagger} \\
(0.009)\end{array}$ & - & $\begin{array}{c}54.19^{\dagger} \\
(0.147)\end{array}$ & $\begin{array}{l}54.06^{\dagger} \\
(0.235)\end{array}$ \\
\hline $\begin{array}{l}\text { Average Locus } \\
\text { of Control }\end{array}$ & - & $\begin{array}{l}47171 \\
(1780)\end{array}$ & $\begin{array}{l}47062 \\
(2608)\end{array}$ & - & $\begin{array}{c}0.469^{\dagger} \\
(0.008)\end{array}$ & $\begin{array}{c}0.462^{\dagger} \\
(0.011)\end{array}$ & - & $\begin{array}{l}52.25^{\dagger} \\
(0.145)\end{array}$ & $\begin{array}{l}52.11^{\dagger} \\
(0.236)\end{array}$ \\
\hline $\begin{array}{l}\text { External Locus } \\
\text { of Control }\end{array}$ & - & $\begin{array}{l}45086 \\
(2120)\end{array}$ & $\begin{array}{l}44901 \\
(2907)\end{array}$ & - & $\begin{array}{c}0.370 \\
(0.009)\end{array}$ & $\begin{array}{c}0.354 \\
(0.012)\end{array}$ & - & $\begin{array}{c}48.37 \\
(0.173)\end{array}$ & $\begin{array}{l}48.75 \\
(0.236)\end{array}$ \\
\hline \multicolumn{10}{|c|}{ High School Dropouts } \\
\hline $\begin{array}{l}\text { Internal Locus } \\
\text { of Control }\end{array}$ & - & $\begin{array}{l}40100^{\dagger} \\
(3490)\end{array}$ & $\begin{array}{l}36665^{\dagger} \\
(3582)\end{array}$ & - & $\begin{array}{c}0.144^{\dagger} \\
(0.015)\end{array}$ & $\begin{array}{c}0.241 \\
(0.015)\end{array}$ & - & $\begin{array}{l}45.63^{\dagger} \\
(0.441)\end{array}$ & $\begin{array}{l}45.94^{\dagger} \\
(0.468)\end{array}$ \\
\hline $\begin{array}{l}\text { Average Locus } \\
\text { of Control }\end{array}$ & - & $\begin{array}{l}43557 \\
(4229)\end{array}$ & $\begin{array}{l}41487 \\
(4678)\end{array}$ & - & $\begin{array}{c}0.293 \\
(0.018)\end{array}$ & $\begin{array}{c}0.278 \\
(0.020)\end{array}$ & - & $\begin{array}{c}44.44^{\dagger} \\
(0.354)\end{array}$ & $\begin{array}{l}45.17^{\dagger} \\
(0.395)\end{array}$ \\
\hline $\begin{array}{l}\text { External Locus } \\
\text { of Control }\end{array}$ & - & $\begin{array}{l}51056 \\
(3376)\end{array}$ & $\begin{array}{l}48956 \\
(3975)\end{array}$ & - & $\begin{array}{c}0.266 \\
(0.014)\end{array}$ & $\begin{array}{c}0.246 \\
(0.017)\end{array}$ & - & $\begin{array}{c}42.31 \\
(0.283)\end{array}$ & $\begin{array}{c}43.36 \\
(0.342)\end{array}$ \\
\hline Controls & Yes & No & Yes & Yes & No & Yes & Yes & No & Yes \\
\hline
\end{tabular}

"Statistically different from "External Locus of Control" at the $5 \%$ level. "Statistically different from "External Locus of Control" at the $10 \%$ level. 
Table 5: Stability of Locus of Control over Time: Correlations

\begin{tabular}{llll}
\hline \hline & $\begin{array}{l}8^{\text {th }} \text { Grade Locus of } \\
\text { Control }\end{array}$ & $\begin{array}{l}10^{\text {th }} \text { Grade Locus of } \\
\text { Control }\end{array}$ & $\begin{array}{l}12^{\text {th }} \text { Grade Locus of } \\
\text { Control }\end{array}$ \\
$\begin{array}{l}8^{\text {th }} \text { Grade Locus of } \\
\text { Control }\end{array}$ & 1 & & \\
$\begin{array}{l}10^{\text {th }} \text { Grade Locus of } \\
\text { Control }\end{array}$ & 0.379 & 1 & 1 \\
$\begin{array}{l}12^{\text {th }} \text { Grade Locus of } \\
\text { Control }\end{array}$ & 0.335 & 0.412 & \\
\hline \hline
\end{tabular}

Table 6: Stability of Math Scores over Time: Correlations

\begin{tabular}{llll}
\hline \hline & $8^{\text {th }}$ Grade Math Score & $\begin{array}{l}10^{\text {th }} \text { Grade Math } \\
\text { Score }\end{array}$ & $\begin{array}{l}12^{\text {th }} \text { Grade Math } \\
\text { Score }\end{array}$ \\
$8^{\text {th }}$ Grade Math Score & 1 & & \\
$10^{\text {th }}$ Grade Math & 0.884 & 1 & 1 \\
$\begin{array}{l}\text { Score } \\
12^{\text {th }} \text { Grade Math }\end{array}$ & 0.829 & 0.924 & \\
Score & & & \\
\hline \hline
\end{tabular}

Table 7: Stability of Reading Scores over Time: Correlations

\begin{tabular}{llll}
\hline \hline & $\begin{array}{l}8^{\text {th }} \text { Grade Reading } \\
\text { Score }\end{array}$ & $\begin{array}{l}10^{\text {th }} \text { Grade Reading } \\
\text { Score }\end{array}$ & $\begin{array}{l}12^{\text {th }} \text { Grade Reading } \\
\text { Score }\end{array}$ \\
$\begin{array}{l}8^{\text {th }} \text { Grade Reading } \\
\text { Score }\end{array}$ & 1 & & \\
$10^{\text {th }}$ Grade Reading & 0.812 & 1 & \\
Score & & & 1 \\
$12^{\text {th }}$ Grade Reading & 0.745 & 0.822 & \\
Score & & & \\
\hline \hline
\end{tabular}


Appendix Table 1: Complete Set of Probit Results

\begin{tabular}{|c|c|c|c|c|c|c|c|c|}
\hline \multirow{4}{*}{ Black } & (1) & (2) & (3) & (4) & $(5)$ & (6) & (7) & (8) \\
\hline & \multicolumn{4}{|c|}{ Graduated from High School } & \multicolumn{4}{|c|}{ Attended College } \\
\hline & -0.091 & -0.013 & -0.000 & 0.014 & -0.133 & -0.006 & 0.02 & 0.035 \\
\hline & $(0.011)^{* *}$ & $(0.008)$ & $(0.008)$ & $(0.007)$ & $(0.014)^{* *}$ & -0.015 & -0.014 & $(0.015)^{*}$ \\
\hline \multirow[t]{2}{*}{ Hispanic } & -0.066 & 0.008 & 0.018 & 0.016 & -0.110 & 0.039 & 0.065 & 0.073 \\
\hline & $(0.012) * *$ & $(0.008)$ & $(0.008) *$ & $(0.008) *$ & $(0.015)^{* *}$ & $(0.015)^{* *}$ & $(0.015)^{* *}$ & $(0.015)^{* *}$ \\
\hline \multirow[t]{2}{*}{ Female } & 0.026 & 0.010 & 0.010 & 0.011 & 0.070 & 0.060 & 0.061 & 0.067 \\
\hline & $(0.006)^{* *}$ & $(0.006)$ & $(0.005)$ & $(0.005)^{*}$ & $(0.008) * *$ & $(0.010)^{* *}$ & $(0.010)^{* *}$ & $(0.010)^{* *}$ \\
\hline \multirow[t]{2}{*}{ Urban } & -0.015 & -0.002 & 0.001 & 0.004 & -0.021 & 0.003 & 0.013 & 0.020 \\
\hline & $(0.008)$ & $(0.007)$ & $(0.007)$ & $(0.007)$ & $(0.011)$ & $(0.012)$ & $(0.012)$ & -0.012 \\
\hline \multirow[t]{2}{*}{ Rural } & -0.009 & 0.014 & 0.016 & 0.010 & -0.099 & -0.053 & -0.041 & -0.046 \\
\hline & $(0.008)$ & $(0.006)^{*}$ & $(0.006)^{* *}$ & $(0.006)$ & $(0.010)^{* * *}$ & $(0.011)^{* *}$ & $(0.011)^{* *}$ & $(0.012)^{* *}$ \\
\hline \multirow[t]{2}{*}{ South } & -0.014 & 0.003 & 0.002 & 0.004 & -0.060 & -0.039 & -0.039 & -0.035 \\
\hline & $(0.010)$ & $(0.009)$ & $(0.009)$ & $(0.009)$ & $(0.013) * *$ & $(0.015)^{* *}$ & $(0.015)^{* *}$ & $(0.015)^{*}$ \\
\hline \multirow[t]{2}{*}{ Midwest } & -0.049 & -0.032 & -0.027 & -0.022 & -0.064 & -0.040 & -0.031 & -0.024 \\
\hline & $(0.009)^{* *}$ & $(0.009)^{* *}$ & $(0.009) * *$ & $(0.009)^{*}$ & $(0.012) * *$ & $(0.014) * *$ & $(0.014)^{*}$ & $(0.014)$ \\
\hline \multirow[t]{2}{*}{ West } & -0.044 & -0.023 & -0.018 & -0.012 & -0.070 & -0.056 & -0.045 & -0.035 \\
\hline & $(0.011)^{* *}$ & $(0.010)^{*}$ & $(0.010)$ & $(0.010)$ & $(0.014)^{* *}$ & $(0.016)^{* *}$ & $(0.016)^{* *}$ & $(0.016)^{*}$ \\
\hline \multirow[t]{2}{*}{ Locus of Control } & 0.092 & 0.022 & 0.019 & 0.019 & 0.157 & 0.051 & 0.044 & 0.043 \\
\hline & $(0.004)^{* *}$ & $(0.004) * *$ & $(0.004) * *$ & $(0.004) * *$ & $(0.006)^{* *}$ & $(0.007)^{* *}$ & $(0.007)^{* *}$ & $(0.007)^{* *}$ \\
\hline \multirow[t]{2}{*}{ GPA ( $8^{\text {th }}$ grade $)$} & & 0.099 & 0.094 & 0.086 & & 0.176 & 0.171 & 0.162 \\
\hline & & $(0.004)^{* *}$ & $(0.004) * *$ & $(0.004) * *$ & & $(0.007)^{* *}$ & $(0.007)^{* *}$ & $(0.008)^{* *}$ \\
\hline \multirow[t]{2}{*}{ History } & & 0.001 & 0.000 & 0.000 & & 0.003 & 0.003 & 0.003 \\
\hline & & $(0.000)$ & $(0.000)$ & $(0.000)$ & & $(0.001)^{* *}$ & $(0.001)^{* *}$ & $(0.001)^{* *}$ \\
\hline \multirow[t]{2}{*}{ Math } & & 0.005 & 0.005 & 0.005 & & 0.010 & 0.009 & 0.009 \\
\hline & & $(0.000)^{* *}$ & $(0.000)^{* *}$ & $(0.000)^{* *}$ & & $(0.001)^{* *}$ & $(0.001)^{* *}$ & $(0.001)^{* *}$ \\
\hline \multirow[t]{2}{*}{ Reading } & & -0.000 & -0.001 & -0.000 & & 0.002 & 0.002 & 0.002 \\
\hline & & $(0.000)$ & $(0.000)$ & $(0.000)$ & & $(0.001)^{* *}$ & $(0.001)^{*}$ & $(0.001)^{* *}$ \\
\hline \multirow[t]{2}{*}{ Science } & & 0.001 & 0.001 & 0.001 & & -0.002 & -0.002 & -0.002 \\
\hline & & $(0.000)$ & $(0.000)$ & $(0.000)$ & & $(0.001)^{*}$ & $(0.001)^{*}$ & $(0.001)^{*}$ \\
\hline \multirow[t]{2}{*}{ Father HS Grad } & & 0.036 & 0.029 & 0.027 & & 0.045 & 0.028 & 0.027 \\
\hline & & $(0.006)^{* *}$ & $(0.006)^{* *}$ & $(0.006)^{* *}$ & & $(0.012)^{* *}$ & $(0.012)^{*}$ & $(0.013)^{*}$ \\
\hline \multirow[t]{2}{*}{ Father Some Coll } & & 0.052 & 0.044 & 0.040 & & 0.106 & 0.085 & 0.087 \\
\hline & & $(0.007)^{* *}$ & $(0.007)^{* *}$ & $(0.007)^{* *}$ & & $(0.013)^{* *}$ & $(0.014)^{* *}$ & $(0.014)^{* *}$ \\
\hline \multirow[t]{2}{*}{ Father Coll Grad } & & 0.080 & 0.065 & 0.060 & & 0.188 & 0.144 & 0.142 \\
\hline & & $(0.007)^{* *}$ & $(0.008)^{* *}$ & $(0.008) * *$ & & $(0.013)^{* *}$ & $(0.015)^{* *}$ & $(0.015)^{* *}$ \\
\hline \multirow[t]{2}{*}{ Mother HS Grad } & & 0.014 & 0.010 & 0.009 & & 0.027 & 0.019 & 0.014 \\
\hline & & $(0.009)$ & $(0.008)$ & $(0.008)$ & & $(0.013)^{*}$ & $(0.013)$ & $(0.014)$ \\
\hline \multirow[t]{2}{*}{ Mother Some Coll } & & 0.023 & 0.015 & 0.015 & & 0.085 & 0.063 & 0.057 \\
\hline & & $(0.010)^{*}$ & $(0.010)$ & $(0.010)$ & & $(0.015)^{* *}$ & $(0.015)^{* *}$ & $(0.016)^{* *}$ \\
\hline \multirow[t]{2}{*}{ Mother Coll Grad } & & 0.012 & -0.001 & 0.002 & & 0.113 & 0.079 & 0.079 \\
\hline & & $(0.012)$ & $(0.013)$ & $(0.013)$ & & $(0.017)^{* *}$ & $(0.017)^{* *}$ & $(0.018)^{* *}$ \\
\hline Discuss w/ Parents & & & 0.003 & 0.002 & & & 0.008 & 0.007 \\
\hline & & & $(0.003)$ & $(0.003)$ & & & $(0.001)^{* *}$ & $(0.001)^{* *}$ \\
\hline Encyclopedia & & & 0.040 & 0.032 & & & 0.065 & 0.055 \\
\hline
\end{tabular}




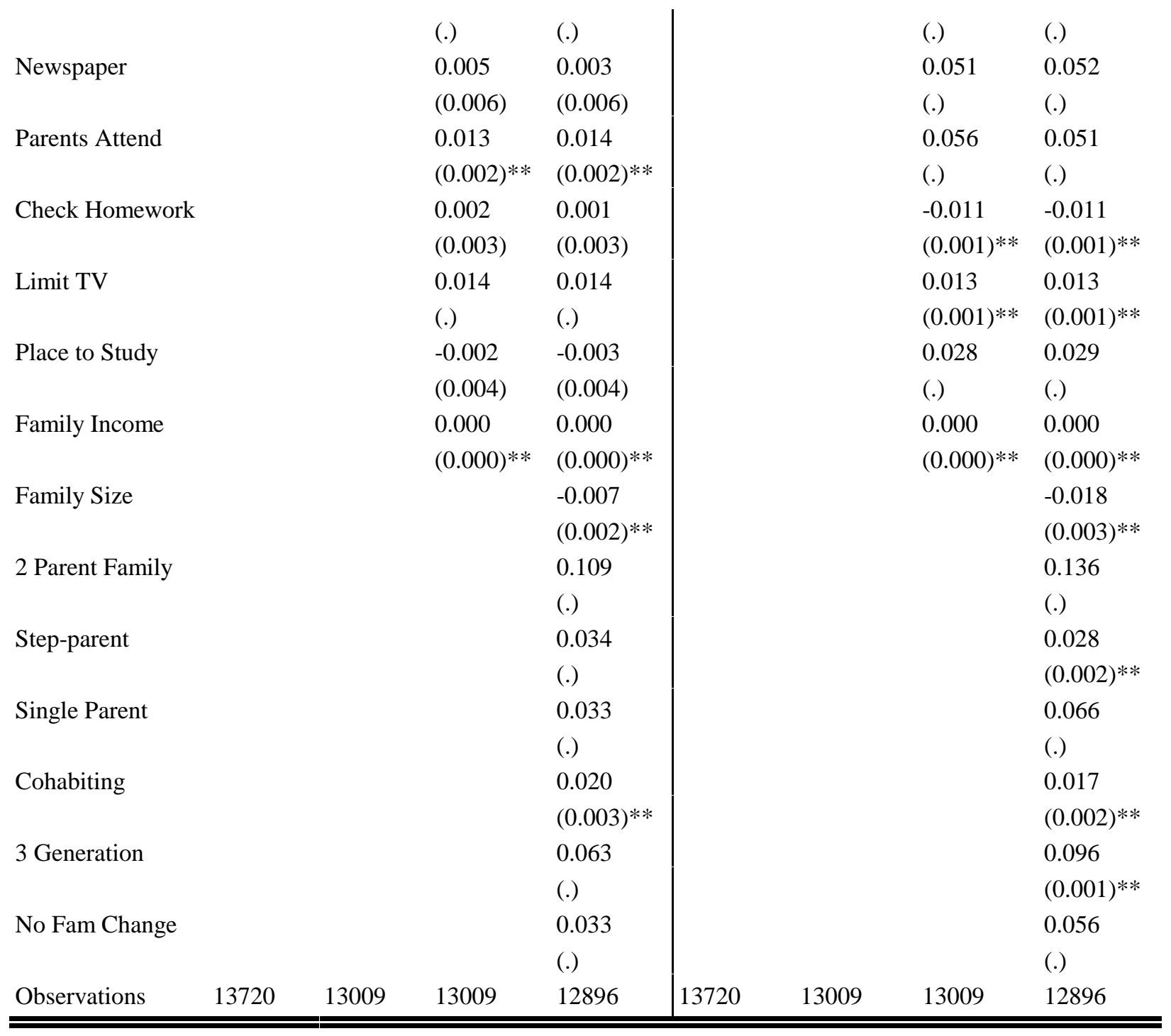

Standard errors in parentheses

* significant at 5\% level; ** significant at $1 \%$ level 
Appendix Table 2: Complete Set of Probit Results: Effects of Locus of Control on Educational Attainment: Marginal Effects from a Probit Analysis (with Race and Gender Interactions)

\begin{tabular}{|c|c|c|c|c|c|c|c|c|}
\hline & (1) & (2) & (3) & (4) & (5) & (6) & (7) & (8) \\
\hline \multirow[b]{2}{*}{ Black } & \multicolumn{4}{|c|}{ Graduate from High School } & \multicolumn{4}{|c|}{ Attend College } \\
\hline & $\begin{array}{l}-0.089 \\
(0.011)^{* *}\end{array}$ & $\begin{array}{l}-0.003 \\
(0.088)\end{array}$ & $\begin{array}{l}0.002 \\
(0.009)\end{array}$ & $\begin{array}{l}0.002 \\
(0.009)\end{array}$ & $\begin{array}{l}-0.132 \\
(0.014)^{* *}\end{array}$ & $\begin{array}{l}-0.001 \\
-0.015\end{array}$ & $\begin{array}{l}0.024 \\
-0.015\end{array}$ & $\begin{array}{l}0.039 \\
(0.015)^{* *}\end{array}$ \\
\hline Hispanic & $\begin{array}{l}-0.06 \\
(0.012)^{* *}\end{array}$ & $\begin{array}{l}0.013 \\
(0.009)\end{array}$ & $\begin{array}{l}0.019 \\
(0.009)^{* *}\end{array}$ & $\begin{array}{l}0.019 \\
(0.008)^{* *}\end{array}$ & $\begin{array}{l}-0.11 \\
(0.015)^{* *}\end{array}$ & $\begin{array}{l}0.038 \\
(0.015)^{*}\end{array}$ & $\begin{array}{l}0.064 \\
(0.015) * *\end{array}$ & $\begin{array}{l}0.072 \\
(0.015)^{* *}\end{array}$ \\
\hline Female & $\begin{array}{l}0.026 \\
(0.006)^{* *}\end{array}$ & $\begin{array}{l}0.010 \\
(0.006)\end{array}$ & $\begin{array}{l}0.010 \\
(0.006)\end{array}$ & $\begin{array}{l}0.011 \\
(0.005)^{*}\end{array}$ & $\begin{array}{l}0.07 \\
(0.008) * *\end{array}$ & $\begin{array}{l}0.06 \\
(0.010)^{* *}\end{array}$ & $\begin{array}{l}0.061 \\
(0.010)^{* *}\end{array}$ & $\begin{array}{l}0.066 \\
(0.010)^{* *}\end{array}$ \\
\hline Urban & $\begin{array}{l}-0.015 \\
(0.008)\end{array}$ & $\begin{array}{l}0.002 \\
(0.007)\end{array}$ & $\begin{array}{l}0.001 \\
(0.007)\end{array}$ & $\begin{array}{l}0.004 \\
(0.007)\end{array}$ & $\begin{array}{l}-0.021 \\
-0.011\end{array}$ & $\begin{array}{l}0.002 \\
-0.012\end{array}$ & $\begin{array}{l}0.013 \\
-0.012\end{array}$ & $\begin{array}{l}0.019 \\
-0.012\end{array}$ \\
\hline Rural & $\begin{array}{l}-0.009 \\
(0.008)\end{array}$ & $\begin{array}{l}0.013 \\
(0.006)^{*}\end{array}$ & $\begin{array}{l}0.016 \\
(0.006)^{*}\end{array}$ & $\begin{array}{l}0.01 \\
(0.006)\end{array}$ & $\begin{array}{l}-0.099 \\
(0.010)^{* *}\end{array}$ & $\begin{array}{l}-0.053 \\
(0.011)^{* *}\end{array}$ & $\begin{array}{l}-0.042 \\
(0.011)^{* *}\end{array}$ & $\begin{array}{l}-0.046 \\
(0.012)^{* *}\end{array}$ \\
\hline South & $\begin{array}{l}-0.014 \\
(0.010)\end{array}$ & $\begin{array}{l}0.003 \\
(0.009)\end{array}$ & $\begin{array}{l}0.002 \\
(0.009)\end{array}$ & $\begin{array}{l}0.004 \\
(0.009)\end{array}$ & $\begin{array}{l}-0.06 \\
(0.013) * *\end{array}$ & $\begin{array}{l}-0.038 \\
(0.015)^{* *}\end{array}$ & $\begin{array}{l}-0.038 \\
(0.015)^{* *}\end{array}$ & $\begin{array}{l}-0.034 \\
(0.015)^{*}\end{array}$ \\
\hline Midwest & $\begin{array}{l}-0.049 \\
(0.009)^{* *}\end{array}$ & $\begin{array}{l}-0.031 \\
(0.009)^{* *}\end{array}$ & $\begin{array}{l}-0.027 \\
(0.009)^{* *}\end{array}$ & $\begin{array}{l}-0.022 \\
(0.009)^{*}\end{array}$ & $\begin{array}{l}-0.064 \\
(0.012)^{* *}\end{array}$ & $\begin{array}{l}-0.039 \\
(0.014)^{* *}\end{array}$ & $\begin{array}{l}-0.031 \\
(0.014)^{*}\end{array}$ & $\begin{array}{r}-0.024 \\
-0.014\end{array}$ \\
\hline West & $\begin{array}{l}-0.044 \\
(0.011)^{* *}\end{array}$ & $\begin{array}{l}-0.022 \\
(0.010)^{*}\end{array}$ & $\begin{array}{l}-0.018 \\
(0.010)\end{array}$ & $\begin{array}{l}-0.012 \\
(0.010)\end{array}$ & $\begin{array}{l}-0.07 \\
(0.014) * *\end{array}$ & $\begin{array}{l}-0.055 \\
(0.016)^{* *}\end{array}$ & $\begin{array}{l}-0.045 \\
(0.016)^{* *}\end{array}$ & $\begin{array}{l}-0.034 \\
(0.016)^{*}\end{array}$ \\
\hline $\begin{array}{l}\text { Locus of Control } \\
* \text { White }\end{array}$ & $\begin{array}{l}0.085 \\
(0.036)^{* *}\end{array}$ & $\begin{array}{l}0.018 \\
(0.004)^{* *}\end{array}$ & $\begin{array}{l}0.018 \\
(0.004)^{* *}\end{array}$ & $\begin{array}{l}0.018 \\
(0.004)^{* *}\end{array}$ & $\begin{array}{l}0.156 \\
(0.007)^{* *}\end{array}$ & $\begin{array}{l}0.043 \\
(0.008) * *\end{array}$ & $\begin{array}{l}0.036 \\
(0.008)^{* *}\end{array}$ & $\begin{array}{l}0.035 \\
(0.008)^{* *}\end{array}$ \\
\hline $\begin{array}{l}\text { Locus of Control } \\
* \text { Black }\end{array}$ & $\begin{array}{l}0.103 \\
(0.038)^{* *}\end{array}$ & $\begin{array}{l}0.028 \\
(0.009)^{* *}\end{array}$ & $\begin{array}{l}0.018 \\
(0.009)^{*}\end{array}$ & $\begin{array}{l}0.018 \\
(0.009)^{*}\end{array}$ & $\begin{array}{l}0.011 \\
-0.017\end{array}$ & $\begin{array}{l}0.056 \\
(0.018)^{* *}\end{array}$ & $\begin{array}{l}0.052 \\
(0.018)^{* *}\end{array}$ & $\begin{array}{l}0.047 \\
(0.018)^{*}\end{array}$ \\
\hline $\begin{array}{l}\text { Locus of Control } \\
* \text { Hispanic }\end{array}$ & $\begin{array}{l}0.122 \\
(0.038) * *\end{array}$ & $\begin{array}{l}0.040 \\
(0.011)^{* *}\end{array}$ & $\begin{array}{l}0.032 \\
(0.010)^{* *}\end{array}$ & $\begin{array}{l}0.032 \\
(0.010)^{* *}\end{array}$ & $\begin{array}{l}-0.002 \\
-0.018\end{array}$ & $\begin{array}{l}-0.002 \\
-0.019\end{array}$ & $\begin{array}{l}0.001 \\
-0.019\end{array}$ & $\begin{array}{l}0.002 \\
-0.019\end{array}$ \\
\hline GPA ( $8^{\text {th }}$ Grade $)$ & - & $\begin{array}{l}0.099 \\
(0.004)^{* *}\end{array}$ & $\begin{array}{l}0.094 \\
(0.004) * *\end{array}$ & $\begin{array}{l}0.086 \\
(0.004)^{* *}\end{array}$ & - & $\begin{array}{l}0.177 \\
(0.007)^{* *}\end{array}$ & $\begin{array}{l}0.172 \\
(0.007)^{* *}\end{array}$ & $\begin{array}{l}0.163 \\
(0.008)^{* *}\end{array}$ \\
\hline History & - & $\begin{array}{l}0.001 \\
(0.000)\end{array}$ & $\begin{array}{l}0.000 \\
(0.000)\end{array}$ & $\begin{array}{l}0.000 \\
(0.000)\end{array}$ & - & $\begin{array}{l}0.003 \\
(0.001)^{* *}\end{array}$ & $\begin{array}{l}0.003 \\
(0.001)^{* *}\end{array}$ & $\begin{array}{l}0.003 \\
(0.001)^{* *}\end{array}$ \\
\hline Math & - & $\begin{array}{l}0.005 \\
(0.000)^{* *}\end{array}$ & $\begin{array}{l}0.005 \\
(0.000)^{* *}\end{array}$ & $\begin{array}{l}0.005 \\
(0.000)^{* *}\end{array}$ & - & $\begin{array}{l}0.01 \\
(0.001)^{* *}\end{array}$ & $\begin{array}{l}0.009 \\
(0.001)^{* *}\end{array}$ & $\begin{array}{l}0.009 \\
(0.001)^{* *}\end{array}$ \\
\hline Reading & - & $\begin{array}{l}0.000 \\
(0.000)\end{array}$ & $\begin{array}{l}-0.001 \\
(0.000)\end{array}$ & $\begin{array}{l}0.000 \\
(0.000)\end{array}$ & - & $\begin{array}{l}0.002 \\
(0.001)^{* *}\end{array}$ & $\begin{array}{l}0.002 \\
(0.001)^{* *}\end{array}$ & $\begin{array}{l}0.002 \\
(0.001)^{* *}\end{array}$ \\
\hline Science & - & $\begin{array}{l}0.001 \\
(0.000)\end{array}$ & $\begin{array}{l}0.001 \\
(0.000)\end{array}$ & $\begin{array}{l}0.001 \\
(0.000)\end{array}$ & - & $\begin{array}{l}-0.002 \\
(0.001)^{*}\end{array}$ & $\begin{array}{l}-0.002 \\
(0.001)^{*}\end{array}$ & $\begin{array}{l}-0.002 \\
(0.001)^{*}\end{array}$ \\
\hline Father HS Grad & - & $\begin{array}{l}0.036 \\
(0.006)^{* *}\end{array}$ & $\begin{array}{l}0.029 \\
(0.006) * *\end{array}$ & $\begin{array}{l}0.027 \\
(0.006)^{* *}\end{array}$ & - & $\begin{array}{l}0.044 \\
(0.012) * *\end{array}$ & $\begin{array}{l}0.028 \\
(0.012)^{*}\end{array}$ & $\begin{array}{l}0.027 \\
(0.013)^{*}\end{array}$ \\
\hline Father Some Coll & - & $\begin{array}{l}0.052 \\
(0.007)^{* *}\end{array}$ & $\begin{array}{l}0.044 \\
(0.007)^{* *}\end{array}$ & $\begin{array}{l}0.04 \\
(0.007)^{* *}\end{array}$ & - & $\begin{array}{l}0.107 \\
(0.013) * *\end{array}$ & $\begin{array}{l}0.086 \\
(0.014)^{* *}\end{array}$ & $\begin{array}{l}0.087 \\
(0.014)^{* *}\end{array}$ \\
\hline Father Coll Grad & - & $\begin{array}{l}0.081 \\
(0.007)^{* *}\end{array}$ & $\begin{array}{l}0.065 \\
(0.008) * *\end{array}$ & $\begin{array}{l}0.06 \\
(0.008)^{* *}\end{array}$ & - & $\begin{array}{l}0.189 \\
(0.013)^{* *}\end{array}$ & $\begin{array}{l}0.144 \\
(0.015)^{* *}\end{array}$ & $\begin{array}{l}0.143 \\
(0.015)^{* *}\end{array}$ \\
\hline Mother HS Grad & - & $\begin{array}{l}0.014 \\
(0.009)\end{array}$ & $\begin{array}{l}0.01 \\
(0.008)\end{array}$ & $\begin{array}{l}0.009 \\
(0.008)\end{array}$ & - & $\begin{array}{l}0.027 \\
(0.013) *\end{array}$ & $\begin{array}{l}0.019 \\
-0.013\end{array}$ & $\begin{array}{l}0.014 \\
-0.014\end{array}$ \\
\hline Mother Some Coll & - & 0.023 & 0.015 & 0.015 & - & 0.084 & 0.061 & 0.056 \\
\hline
\end{tabular}




\begin{tabular}{|c|c|c|c|c|c|c|c|c|}
\hline & & $(0.010)^{*}$ & $(0.010)$ & $(0.010)$ & & $(0.015)^{* *}$ & $(0.015)^{* *}$ & $(0.016)^{* *}$ \\
\hline Mother Coll Grad & - & $\begin{array}{l}0.012 \\
-0.013\end{array}$ & $\begin{array}{l}-0.001 \\
(0.013)\end{array}$ & $\begin{array}{l}0.002 \\
(0.013)\end{array}$ & - & $\begin{array}{l}0.113 \\
(0.017)^{* *}\end{array}$ & $\begin{array}{l}0.079 \\
(0.017) * *\end{array}$ & $\begin{array}{l}0.079 \\
(0.018)^{* *}\end{array}$ \\
\hline Discuss w/ Parents & - & - & $\begin{array}{l}0.003 \\
(0.003)\end{array}$ & $\begin{array}{l}0.002 \\
(0.003)\end{array}$ & - & - & $\begin{array}{l}0.008 \\
(0.001)^{* *}\end{array}$ & $\begin{array}{l}0.007 \\
(0.001)^{* *}\end{array}$ \\
\hline Encyclopedia & - & - & $\begin{array}{l}0.039 \\
(0.009)^{* *}\end{array}$ & $\begin{array}{l}0.032 \\
(0.008)^{* *}\end{array}$ & - & - & $\begin{array}{l}0.064 \\
(.)\end{array}$ & $\begin{array}{l}0.054 \\
(.)\end{array}$ \\
\hline Newspaper & - & - & $\begin{array}{l}0.006 \\
(0.005)\end{array}$ & $\begin{array}{l}0.003 \\
(0.006)\end{array}$ & - & - & $\begin{array}{l}0.051 \\
(.)\end{array}$ & $\begin{array}{l}0.051 \\
(.)\end{array}$ \\
\hline Parents Attend & - & - & $\begin{array}{l}0.013 \\
(0.002)^{* *}\end{array}$ & $\begin{array}{l}0.014 \\
(0.001)^{* *}\end{array}$ & - & - & $\begin{array}{l}0.056 \\
(.)\end{array}$ & $\begin{array}{l}0.051 \\
(.)\end{array}$ \\
\hline Check Homework & - & - & $\begin{array}{l}0.002 \\
(0.003)\end{array}$ & $\begin{array}{l}0.001 \\
(0.003)\end{array}$ & - & - & $\begin{array}{l}-0.011 \\
(0.001)^{* *}\end{array}$ & $\begin{array}{l}-0.01 \\
(0.001)^{* *}\end{array}$ \\
\hline Limit TV & - & - & $\begin{array}{l}0.014 \\
(0.005)^{* *}\end{array}$ & $\begin{array}{l}0.014 \\
(0.005)^{* *}\end{array}$ & - & - & $\begin{array}{l}0.012 \\
(0.001)^{* *}\end{array}$ & $\begin{array}{l}0.012 \\
(0.001)^{* *}\end{array}$ \\
\hline Place to Study & - & - & $\begin{array}{l}-0.002 \\
(0.004)\end{array}$ & $\begin{array}{l}-0.003 \\
(0.004)\end{array}$ & - & - & $\begin{array}{l}0.029 \\
(.)\end{array}$ & $\begin{array}{l}0.03 \\
(.)\end{array}$ \\
\hline Family Income & - & - & $\begin{array}{l}9.5 \mathrm{e} 7 \\
(9.8 \mathrm{e} 8)^{* *}\end{array}$ & $\begin{array}{l}5.1 \mathrm{e} 7 \\
(1.0 \mathrm{e} 7)^{* *}\end{array}$ & - & - & $\begin{array}{l}0 \\
(0.000)^{* *}\end{array}$ & $\begin{array}{l}0 \\
(0.000)^{* *}\end{array}$ \\
\hline Family Size & - & - & - & $\begin{array}{l}-0.007 \\
(0.002)^{* *}\end{array}$ & - & - & - & $\begin{array}{l}-0.019 \\
(0.003)^{* *}\end{array}$ \\
\hline 2 Parent Family & - & - & - & $\begin{array}{l}0.108 \\
(0.015)^{* *}\end{array}$ & - & - & - & $\begin{array}{l}0.137 \\
(.)\end{array}$ \\
\hline Step-parent & - & - & - & $\begin{array}{l}0.034 \\
(0.010)^{* *}\end{array}$ & - & - & - & $\begin{array}{l}0.029 \\
(0.002)^{* *}\end{array}$ \\
\hline Single Parent & - & - & - & $\begin{array}{l}0.032 \\
(0.010) * *\end{array}$ & - & - & - & $\begin{array}{l}0.067 \\
(.)\end{array}$ \\
\hline Cohabiting & - & - & - & $\begin{array}{l}0.020 \\
(0.003) * *\end{array}$ & - & - & - & $\begin{array}{l}0.018 \\
(0.002)^{* *}\end{array}$ \\
\hline 3 Generation & - & - & - & $\begin{array}{l}0.063 \\
(0.009) * *\end{array}$ & - & - & - & $\begin{array}{l}0.099 \\
(.)\end{array}$ \\
\hline No Fam Change & - & - & - & $\begin{array}{l}0.033 \\
(0.006) * *\end{array}$ & - & - & - & $\begin{array}{l}0.056 \\
(.)\end{array}$ \\
\hline Observations & 13720 & 13009 & 13009 & 12896 & 13720 & 13009 & 13009 & 12896 \\
\hline
\end{tabular}

Standard errors in parentheses

* significant at $5 \%$ level; ** significant at $1 \%$ level 
Appendix Table 3: Complete Set of Regression Results for Expectations and Ability

\begin{tabular}{|c|c|c|c|c|c|c|c|c|c|}
\hline \multirow{4}{*}{ Black } & (1) & & \multirow[t]{2}{*}{ (3) } & \multirow{2}{*}{\multicolumn{3}{|c|}{$\begin{array}{l}(4) \\
\text { Expect a High Skill Occupation }\end{array}$}} & \multicolumn{3}{|c|}{$\begin{array}{ll}(8) & (9)\end{array}$} \\
\hline & \multicolumn{2}{|c|}{ Income Expectations } & & & & & \multicolumn{3}{|c|}{$8^{\text {th }}$ Grade math Achievement } \\
\hline & 13191.425 & & 13428.824 & 0.018 & & 0.032 & -6.515 & & -5.955 \\
\hline & $(3,110.192)^{* *}$ & & $(3,118.262)^{* *}$ & $(0.013)$ & & $(0.013)^{*}$ & $(0.259)^{* *}$ & & $(0.250)^{* *}$ \\
\hline \multirow[t]{2}{*}{ Hispanic } & -8295.896 & & $-8,343.674$ & 0.002 & & 0.009 & -5.577 & & -5.142 \\
\hline & $(3,383.547)^{*}$ & & $(3,388.099)^{*}$ & $(0.014)$ & & $(0.014)$ & $(0.280)^{* *}$ & & $(0.271)^{* *}$ \\
\hline \multirow[t]{2}{*}{ Female } & -17610.975 & & $-18,049.246$ & 0.149 & & 0.137 & -0.463 & & -0.594 \\
\hline & $(1,895.876)^{* *}$ & & $(1,901.898)^{* *}$ & $(0.008)^{* *}$ & & $(0.008)^{* *}$ & $(0.162)^{* *}$ & & $(0.156)^{* *}$ \\
\hline \multirow[t]{2}{*}{ Urban } & 4426.558 & & $4,105.941$ & 0.090 & & 0.085 & -0.493 & & -0.465 \\
\hline & -2475.927 & & $(2,477.281)$ & $(0.010) * *$ & & $(0.010)^{* *}$ & $(0.208)^{*}$ & & $(0.201)^{*}$ \\
\hline \multirow[t]{2}{*}{ Rural } & -4626.456 & & $-4,912.438$ & 0.029 & & 0.024 & -1.669 & & -1.617 \\
\hline & $(2,303.143)^{*}$ & & $(2,304.243)^{*}$ & $(0.010) * *$ & & $(0.010)^{*}$ & $(0.192)^{* *}$ & & $(0.185)^{* *}$ \\
\hline \multirow[t]{2}{*}{ South } & 3402.188 & & $2,699.584$ & 0.140 & & 0.126 & -0.146 & & -0.067 \\
\hline & -2713.813 & & $(2,722.728)$ & $(0.011)^{* *}$ & & $(0.011)^{* *}$ & $(0.243)$ & & $(0.235)$ \\
\hline \multirow[t]{2}{*}{ Midwest } & 4987.707 & & $4,338.188$ & 0.118 & & 0.110 & -1.440 & & -1.190 \\
\hline & -2615.944 & & $(2,624.050)$ & $(0.011)^{* *}$ & & $(0.011)^{* *}$ & $(0.233)^{* *}$ & & $(0.225)^{* *}$ \\
\hline \multirow[t]{2}{*}{ West } & 14537.953 & & $13,915.252$ & 0.123 & & 0.113 & -0.389 & & -0.164 \\
\hline & $(2,970.565)^{* *}$ & & $(2,976.034)^{* *}$ & $(0.013) * *$ & & $(0.012)^{* *}$ & $(0.265)$ & & $(0.256)$ \\
\hline Internal Locus & 50242.79 & & & 0.244 & & & 55.966 & & \\
\hline of Control & $(1,942.517)^{* *}$ & & & $(0.008)^{* *}$ & & & $(0.240)^{* *}$ & & \\
\hline Average Locus & 49425.305 & & & 0.235 & & & 53.839 & & \\
\hline of Control & $(2,510.746)^{* *}$ & & & $(0.011)^{* *}$ & & & $(0.239)^{* *}$ & & \\
\hline External Locus & 49224.442 & & & 0.125 & & & 50.062 & & \\
\hline of Control & $(2,687.923)^{* *}$ & & & $(0.011)^{* *}$ & & & $(0.255)^{* *}$ & & \\
\hline Dropout* & & $40,100.145$ & 40756.39 & & 0.144 & 0.057 & & 45.623 & 48.459 \\
\hline Internal & & $(3,490.458)^{* *}$ & $(3,582.215)^{* *}$ & & $(0.015)^{* *}$ & $(0.015)^{* *}$ & & $(0.441)^{* *}$ & $(0.468)^{* *}$ \\
\hline Dropout* & & $43,557.696$ & 45579.365 & & 0.293 & 0.094 & & 44.470 & 47.688 \\
\hline Average & & $(4,229.385)^{* *}$ & $(4,677.557)^{* *}$ & & $(0.018)^{* *}$ & $(0.020)^{* *}$ & & $(0.354)^{* *}$ & $(0.395)^{* *}$ \\
\hline Dropout $*$ & & $51,056.201$ & 53046.663 & & 0.266 & 0.062 & & 42.306 & 45.875 \\
\hline External & & $(3,376.022)^{* *}$ & $(3,975.161)^{* *}$ & & $(0.014)^{* *}$ & $(0.017)^{* *}$ & & $(0.283)^{* *}$ & $(0.342)^{* *}$ \\
\hline
\end{tabular}




\begin{tabular}{|c|c|c|c|c|c|c|c|c|c|}
\hline HS Grad* & & $49,425.652$ & 52880.123 & & 0.442 & 0.294 & & 54.187 & 56.580 \\
\hline Internal & & $(1,556.492)^{* *}$ & $(2,116.229)^{* *}$ & & $(0.007)^{* *}$ & $(0.009)^{* *}$ & & $(0.147)^{* *}$ & $(0.235)^{* *}$ \\
\hline HS Grad* & & $47,170.815$ & 51153.644 & & 0.469 & 0.278 & & 52.253 & 54.633 \\
\hline Average & & $(1,779.984)^{* *}$ & $(2,607.957)^{* *}$ & & $(0.008)^{* *}$ & $(0.011)^{* *}$ & & $(0.145)^{* *}$ & $(0.236)^{* *}$ \\
\hline HS Grad* & & $45,086.213$ & 48993.358 & & 0.370 & 0.170 & & 48.370 & 51.264 \\
\hline External & & $(2,119.800)^{* *}$ & $(2,907.298)^{* *}$ & & $(0.009)^{* *}$ & $(0.012)^{* *}$ & & $(0.173)^{* *}$ & $(0.259)^{* *}$ \\
\hline Observations & 14915 & 14915 & 14915 & 14915 & 14915 & 14915 & 13286 & 13286 & 13286 \\
\hline R-squared & 0.16 & 0.15 & 0.16 & 0.43 & 0.42 & 0.44 & 0.97 & 0.97 & 0.97 \\
\hline
\end{tabular}

* significant at $5 \%$ level; ** significant at $1 \%$ level 


\section{Appendix Table 4 Questions that make up the Locus of Control Scale:}

How do you feel about the following statements?

(1) I don't have enough control over the direction my life is taking.

(2) In my life, good luck is more important than hard work for success.

(3) Every time I try to get ahead, something or somebody stops me.

(4) My plans hardly ever work out, so planning only makes me unhappy.

(5) When I make plans, I am almost certain I can make them work.

(6) Chance and luck are very important for what happens in my life. 